\title{
Ngụ Ngôn Bói Cá
}

\section{Vương Quân Hoàng}

Ngày 25 tháng 4 năm 2021

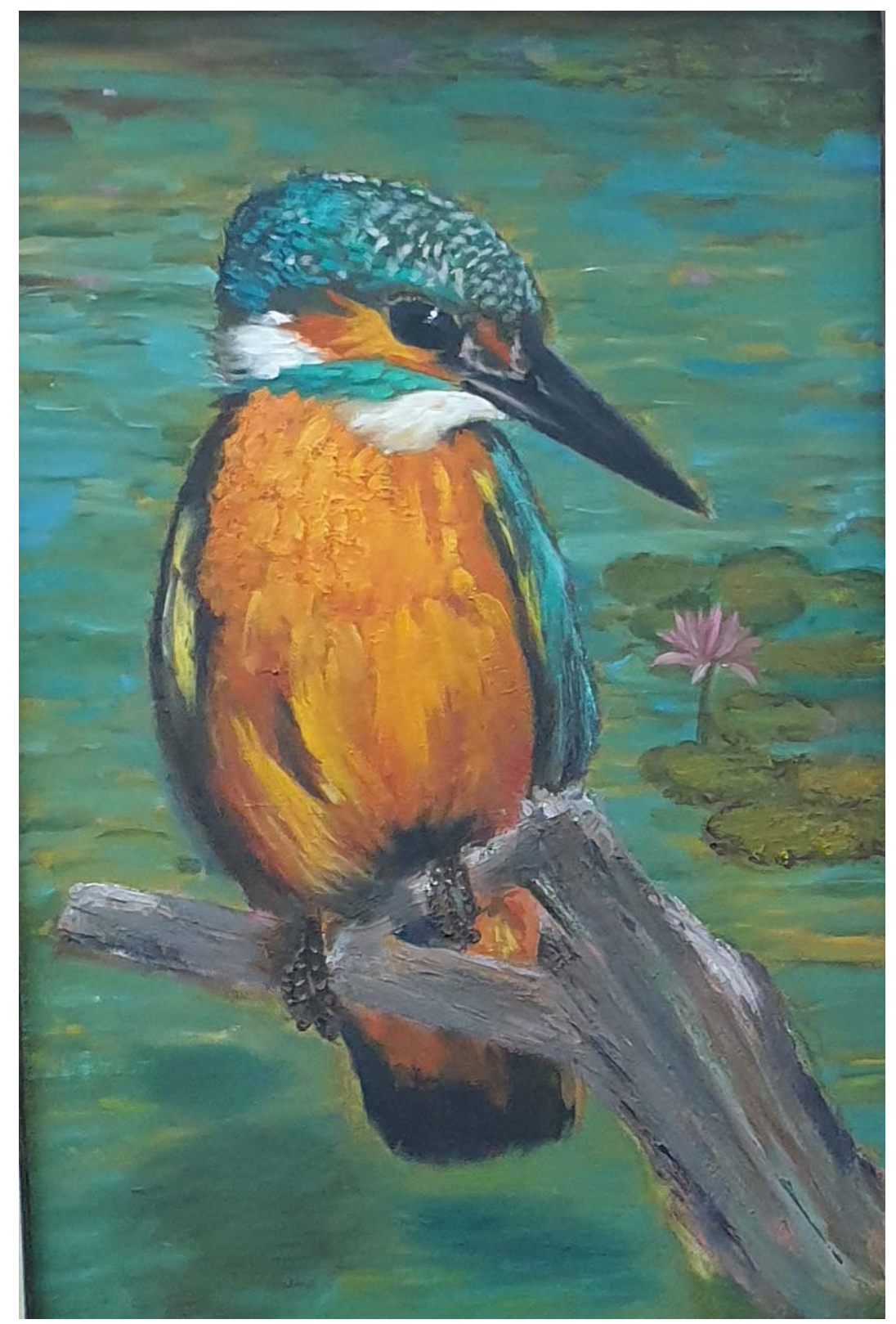

(C2020 Đàm Thu Hà - Bói Cá (tranh sơn dầu) 


\title{
Ngụ Ngôn Bói Cá
}

\author{
Vương Quân Hoàng
}

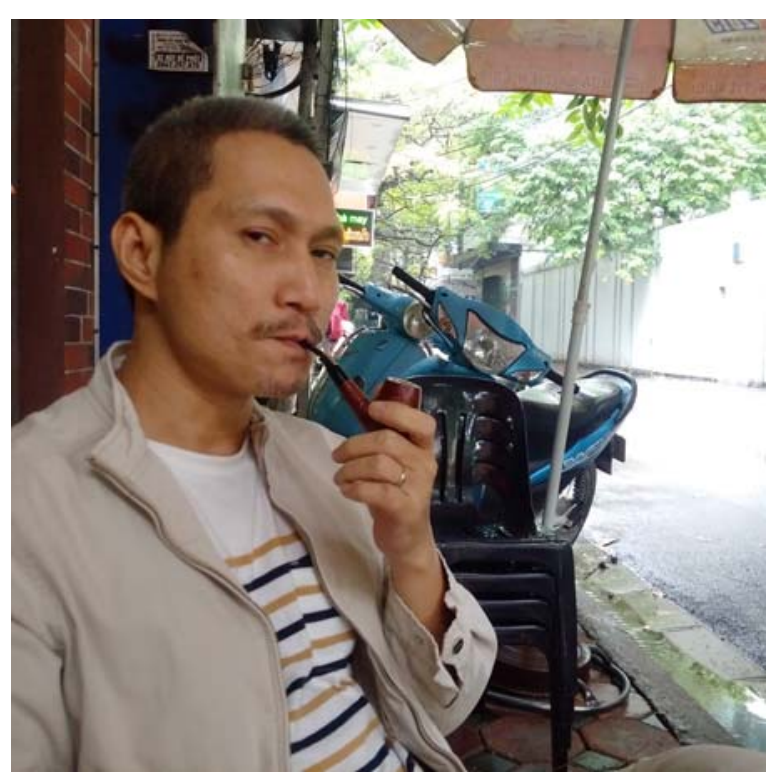

Kinh tế và Dự báo, 2017-2018 


\section{Giới thiệu:}

Những trang tiếp theo gom góp 15 mẩu chuyện ngụ ngôn về nhân vật gọi là Bói-Cá tiên sinh, được viết lại thành dạng truyện ngắn, không có truyện nào dài quá một trang. Nếu để rải rác thì ai có muốn tìm lại cũng khó, nay tôi gom cả lại một tập cho dễ tìm và đọc một lượt là hết.

Các truyện ngụ ngôn này được đăng rải rác trên tờ Kinh tế và Dự báo, ở mục Khoảng Lặng, trong các số thuộc năm 2017 và 2018, dưới bút danh Chấu Chàng.

Tác giả xin chân thành cảm ơn anh Lê Xuân Đình và chị Đỗ Phương Lan, đã động viên (và thúc giục) để chúng phải ra đời đúng lúc. Quả nhiên, sự thúc giục rất quý giá. Vì sau này khi thiếu nó, chẳng có thêm mẩu nào nữa được ra đời.

Các bức tranh cho bài đều của họa sỹ Bùi Quang Khiêm, xin cảm ơn họa sỹ Khiêm.

Vương Quân Hoàng

Hà Nội, ngày 25 tháng 4 năm 2021 


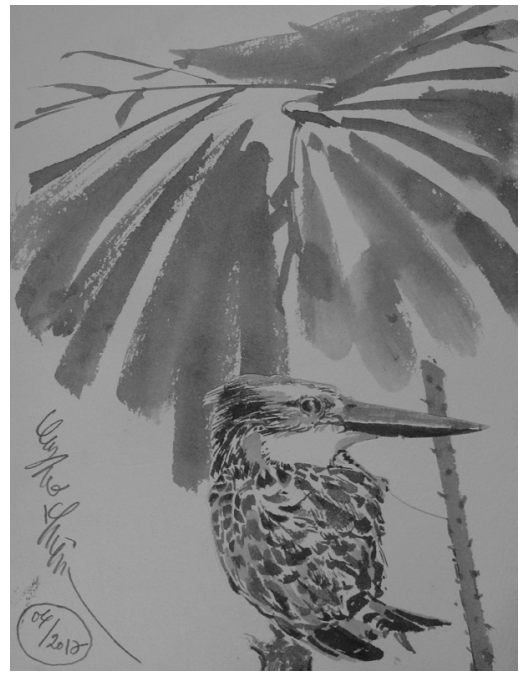

Bùi Quang Khiêm

\section{Lời Ban Biên tập:}

Tạp chí Kinh tế và Dư báo luôn phấn đấu để trở thành người bạn đồng hành cùng với nhũ̃ng thành công của đông đảo bạn đọc gần - xa, trong nước và nước ngoài bằng nhũng thông tin, kiến thức chuyên sâu và hũu ích trong nghiên cứu, phản biện xã hội và hoạch định chính sách. Theo nguyện vọng của đông đảo bạn đọc, tù̀ số này Tạp chí sẽ mở chuyên mục mới với tên gọi KHOẢNG LẶNG, giới thiệu nhũ̃ng mẫu chuyện dạng "ngụ ngôn" vừa khôi hài, châm biếm, vừa thâm thúy để thu giãn, nhuing cũng nói lên những vấn đề bạn đọc quan tâm.

Trân trọng giới thiệu cùng bạn đọc!

\section{Kế hoạch hoàn hảo}

Ngài Bói-Cá hiểu sâu biết rộng, lại cũng có đầu óc lập kế hoạch chi li.

Bữa nay, tờ mờ sáng ngài đã đậu trên cành cao suy tư. Ngài có thể kiểm soát tốc độ bay, khi nhanh lúc chậm. Vậy tính sao cho khi thư thả, lúc khẩn trương, việc bắt cá đỡ tốn sức.

Kinh nghiệm xử lý bọn cá dưới ao giúp ngài đoán biết con nào to hay bé, mau lẹ hay lờ đờ. Nhờ vậy, làm chủ được cơ hội vồ chộp chuẩn nhất, thế mới còn nhiều thời gian để suy ngẫm chuyện thiên địa.

Ngài lại hiểu cả lòng mình, sức vóc ấy ngày mấy bữa, mỗi bữa mấy con, biết rõ sự dành dụm nay mai. Cá con chờ lớn, cá to xơi trước...

Vạn chuyện, ngài tính được cả.

Nghĩ nháp, rồi lên kế hoạch để hành động. Việc "vận trù" ấy ngài cũng thạo lắm. Kế hoạch xong, chưa yên tâm, lại chỉnh. Phàm là sự hoàn hảo thì đòi hỏi kỳ công. Có phải làm lại bao lần Bói-Cá cũng không nề hà... Cứ thế, ngài miệt mài sự nghiệp toán học.

Hết ngày, ngài hết sức tâm đắc với kế hoạch kiếm ăn hoàn hảo được soạn ra. Ngài Bói-Cá thổn thức, không sao ngủ được.

Cảm giác cồn cào ở bụng. Hóa ra Ngài... đói.

Chẫu Chàng 


\section{Nhẹ gánh, thảnh thơi}

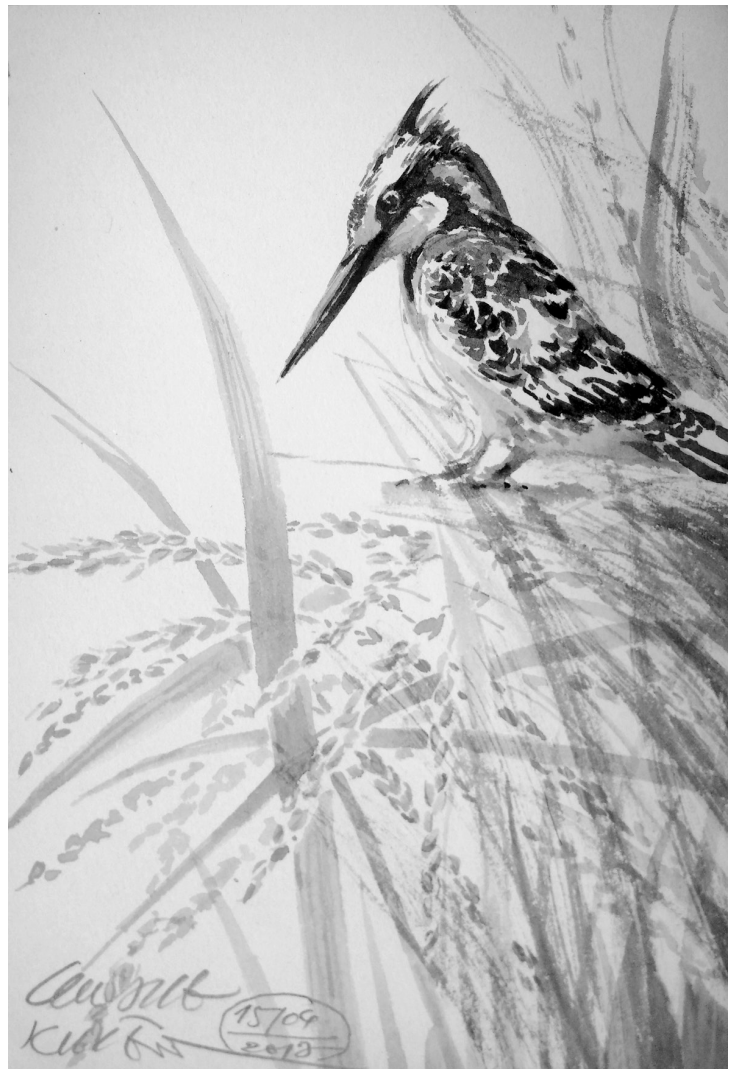

Bùi Quang Khiêm

Dạo này thấy ngài Bói-Cá ít giao thiệp, hay trầm tư. Chim-Gáy tới thăm. Gáy nói:

- Bữa nay trời đẹp, ngài nên đi cùng tôi thăm ruộng lúa. Lúc này sắp mùa gặt, ruộng đông vui, nhiều chim kéo về. Ngài ra đó còn biết thêm nhiều việc đời.

Bói-Cá đã điểm tâm, nên vui vẻ đi cùng Gáy.

Ngài thấy ruộng lúa sắp chín vàng thì xúc động lắm. Đồng ruộng mênh mông, Bói-Cá và Gáy sà vào nơi vàng ruộm.

Bên đám ruộng trông sung túc, được mùa, Bói-Cá lân la hỏi chuyện. Lạ thay chẳng mấy ai trả lời. Anh thì mải gồng chống đỡ gió, anh lại gồng giữ bông, hay bận che chắn bọn chim chóc chỉ chờ vặt hạt chín. Anh nào cũng lưng còng, mặt úp. Mãi mà vẫn chưa được câu nào ra đầu ra đũa.

Thấy Bói-Cá nản, Gáy bảo:

- Ta sang phía bên kia, chỗ ấy lao xao, vui vẻ. Các anh bên ấy vươn lên vẫy chào, có dáng hay chuyện.

Quả nhiên sang bên ấy bắt chuyện được ngay. Tò mò, Bói-Cá hỏi:

- Cùng cánh đồng này sao hai bên tính cách khác nhau? Bên kia đăm đăm, bên này hồ hởi.

Một anh Lúa đang lắc lư theo gió nhanh nhảu:

- Vâng, hoàn cảnh khác nhau. Chúng em nhẹ gánh, thảnh thơi lắm. Các bác bên kia suốt ngày cau có, chăm chăm giữ đám hạt chín. Phí cơ hội hưởng cái vui múa hát, tán gẫu những ngày nắng đẹp...

Vừa nói, anh Lúa ưỡn ngực, dang tay như muốn ôm trời đất vào lòng, mắt long lanh không giấu sự kiêu hãnh. Đôi tay Lúa đập đập vào thân mình đang đu đưa, khiến cánh lá phất phơ.

Bói-Cá mắt tinh nhận ra, phía bên này, anh nào cũng chỉ toàn hạt lép... 

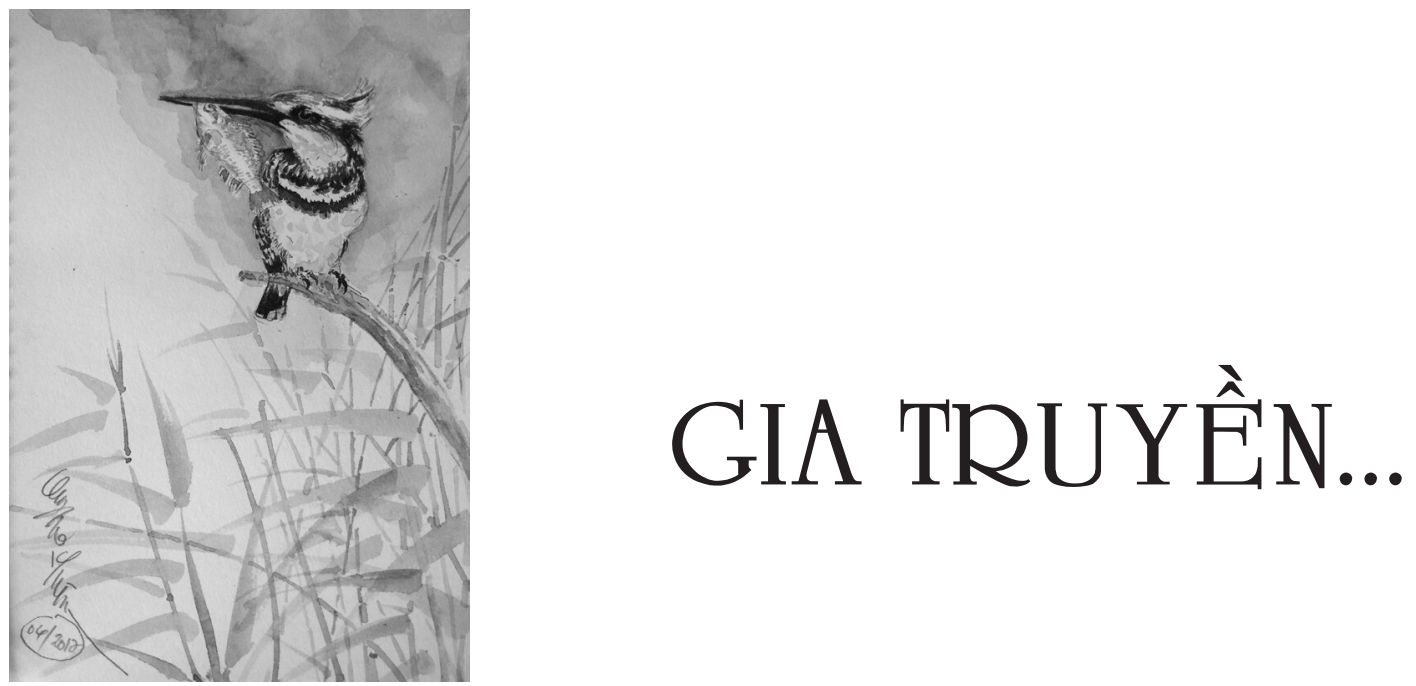

Bùi Quang Khiêm

Xóm chim lao xao mấy hôm rày vì bọn Bồ-Nông lạ. Chúng đến xóm kiếm ăn. Chỉ có ba thằng, nhưng bắt cá chăm chỉ từ sáng đến đêm, ăn rất khỏe. Bói-Cá lo lắng, bay đậu không yên, tối đến bèn đòi họp xóm.

Nể ngài, bọn chim dù đã ngáp ngủ đều đến, vắng mỗi cô Cò. Ngài yêu cầu họp kể tội bọn BồNông, rồi ra quyết định tống cổ bọn quậy phá khỏi xóm.

Đủ các loại ý kiến loạn xạ. Chào-Mào, Liếu-Tiếu cãi hăng còn suýt mổ nhau - dù cùng ý kiến rằng có hết cá thì vẫn còn sâu. Chim Sâu bị khiển trách vì lan man, nhân dịp đông đủ xóm kiện cáo chim sẻ tự tiện vào tổ ngủ trưa. Sáo thì tranh thủ tiếp thị dịch vụ dọn dẹp.

Bói-Cá đập mỏ vào chạc cây, quát:

- Không bàn chuyện xằng nữa. Tất cả tập trung vào việc ăn cá!

Xóm im bặt. Mãi cũng có giọng Chim-Gáy cất lên từng tiếng rành rọt:

- Thưa ông Bói-Cá, nhưng mà ông cũng là tay bắt cá thiện nghệ, và ăn cá chủ lực...

Khó xử, ngài nạt:

- Hỗn. Ta bắt cá có phong cách, ăn cá có đạo lý! Nhiều đời gia truyền đã như thế. Đâu như cái bọn phàm ăn tục uống, chả có lễ nghĩa, lang bạt kiếm ăn...

Chưa dứt lời, bỗng thấy Cò hổn hển xông vào. Té ra, Cò muộn họp vì mải đi rình Bồ-Nông, rồi bị bọn chúng phát hiện. Mãi mới về được.

Bói-Cá hỏi:

- Rồi sao nữa?

Cò: - Dạ, bọn họ to khỏe, mỏ như cái gầu xúc, chỉ sợ lơ mơ phạng cho một nhát là toi đời...

Bói-Cá giục:

- Mày nói mau lên xem nào.

Cò: - Hóa ra, họ hiền lành, thưa gửi lễ phép. Họ đưa cho hai tờ giấy, bảo đọc rồi về báo cáo...

Bói-Cá: - Thế tờ giấy ấy nói gì?

Cò: - Một tờ ghi "Chứng chỉ phong cách và đạo đức bắt cá”. Tờ kia: "Được bắt cá toàn cõi".

Nghe tới đây, tai ngài ù đi, mắt tối sầm, ngất lịm. Bọn chim xúm lại cùng chữa chạy. Lát sau, ngài mở mắt thều thào:

- Nghề bắt cá gia truyền của ta đã đạt cực đỉnh tài hoa, được thiên hạ tôn là "bói”. Thế mà bây giờ mới biết, xưa nay nhà ta toàn đánh bắt lậu!

Chẫu Chàng 


\section{Chim Sư}

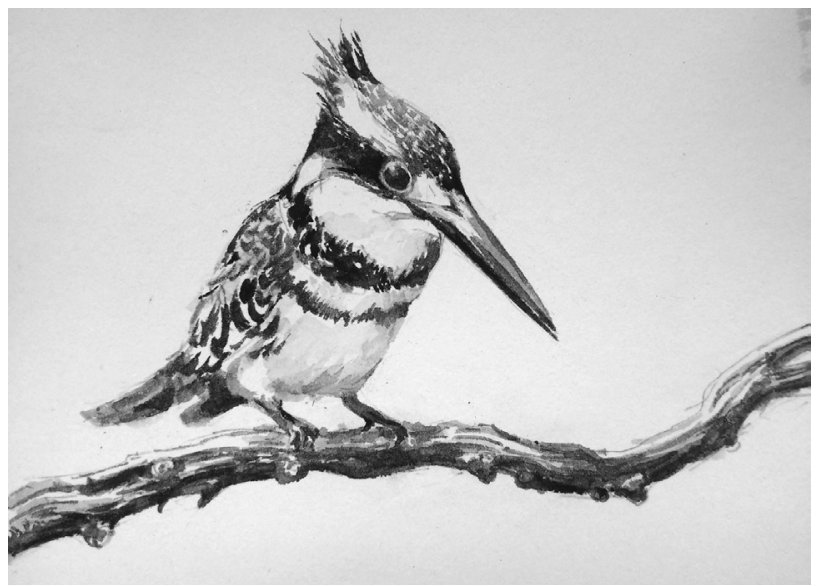

Bùi Quang Khiêm
Wột sáng hè, xóm lặng im. Bọn chim đang chăm chú nghe một tay lang bạt mới xuất hiện. Không biết giống gì, nhưng lông đủ màu, điệu bộ ngộ nghĩnh, kiến thức lạ lẫm. Kể chuyện mà như danh sư giảng bài, nên xóm gọi là Chim-Sư, đáp ứng mọi tò mò của xóm chim ham học. Chim-Sâu học cách tìm sâu buổi chiều, đỡ phải dậy sớm. Bọn Sẻ biết đường trộm lúa trong kho khi ngoài đồng hết thóc. Chào-Mào nắm được tinh thần thời trang để dự thi nhan sắc...

Ngẫm nghĩ, thấy cần nâng tầm nghệ thuật bắt cá, Bói-Cá cũng khẩn khoản nhờ chỉ dậy. Chim-Sư nhận lời chỉ cho ba bí quyết, đổi lại Bói-Cá trả công bằng hiện vật đánh bắt. Khóa học nâng cao diễn ra bên Ao Chẫu. Chim-Sư và Bói-Cá đậu trên cành tre giữa ao. Bọn chim tò mò dự thính đậu loanh quanh.

Đầu tiên, Chim-Sư chỉ ra cần chấm dứt thói bay lượn điệu đà, mất sức. Đánh bắt cá phải cốt ở hiệu quả. Bói-Cá gật gù ghi nhớ.

Tiếp đến, quan sát con mồi vừa sức. Bói-Cá hiểu ngay. Đã vài lần vồ trượt cá bé nhanh nhẹn, chưng hửng bực mình. Lúc gặp phải cá to thì quá sức, có khi còn bị lôi đi suýt toi mạng.

Cuối cùng, cần lao xuống nước tốc độ cao, kẹp mỏ chặt, kiên quyết truy đuổi con mồi dưới nước. Thuận lợi thì đạp nước, vỗ cánh vọt lên. Bói-Cá hoan hỉ, còn đám chim đồng thanh ca ngợi danh sư. Chim-Sư lấy làm đẹp lòng lắm.

Thế rồi, cả bọn năn nỉ xin được thị phạm. Không thể từ chối, Chim-Sư nhận lời. Xóm chim nín thở chờ màn trình diễn.

Quan sát rất nhanh, dường như đã xác định mục tiêu, ngài lao xuống. Thoáng cái ngài đã lặn vào làn nước. Nhìn từ trên thấy trong đáy nước mờ ảo, ngài đang xoay vòng vũ điệu chân-cánh-mỏ giữa cuộc thủy chiến hùng tráng. Thoáng chốc, đã kẹp chặt con mồi. Rõ là phần thắng của Chim-Sư đã phân định từ trước!

Không riêng Bói-Cá mà cả xóm sửng sốt khâm phục, ra sức trầm trồ.

Có điều, mãi ngài chưa vọt lên.

Chờ một lúc, e có chuyện chẳng lành, Bói-Cá lao xuống cấp cứu, mỏ kẹp cổ, chân đỡ cánh, hì hục kéo ngài lên. Tới bờ, Chim-Sư nằm bất tỉnh. Cổ ngoẹo, diều õng nước. Con mồi ngài săn được văng ra: mẩu gỗ mục dài non nửa gang tay./. 


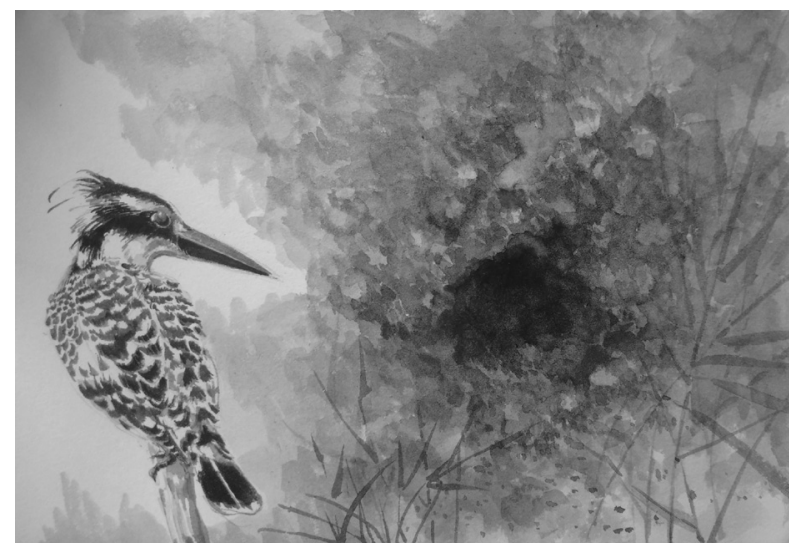

Bùi Quang Khiêm

\section{DINH CO}

Bói-Cá vốn ở hang đào ven ao đã lâu, nay muốn có dinh cơ mới. Ngài đi tham khảo cách xây nhà của bọn chim.

Thăm nhà Sẻ trên cành phi lao trước. Được cái mặt tiền đẹp, trên cao thoáng gió. Nhưng ở chơi một lúc thì chóng mặt. Gặp gió, tổ lắc lư như sắp rụng. Đã vậy, tổ đan thưa bằng cọng phi lao - dù Sẻ bảo chắc lắm - ngài thấy nó chỉ chực bung ra. Ngài đành chào, rồi rẽ qua Chim-Sâu.

Tổ Chim-Sâu nằm ở chạc cây mít, nơi thấp hơn, nhưng bền tốt, làm bằng cọng tẻ xuyến chi, vừa dai vừa dài. Nhà rộng, đủ cho chục trứng, còn có chỗ tiếp khách. Bói-Cá hỏi cách làm, Chim-Sâu vui vẻ hướng dẫn. Trước tiên, dẫn bay rụng cánh chọn được chục cọng. Về lọc còn được hai ba. Rồi cắt, chuốt, đan sợi. Chim-Sâu khéo léo, chân giữ sợi, mỏ luồn, chân kéo buộc, đều và nhanh. Bói-Cá loay hoay cả giờ, không được sợi nào ra hồn... cứ làm đi, rồi hỏng lại.

Nản. Ngài buông. Bóp đầu nghĩ cách nhàn hơn.

Bói-Cá bay lòng vòng, chẳng mấy chốc soi được một tổ mối lớn. Bọn mối bỏ đi, để lại thành quách bề thế. Bên trong rộng, nhiều ngóc ngách. Ngài chỉ dùng mỏ và chân gạt qua gạt lại, đắp đắp, đào đào chừng đôi giờ đã có cơ ngơi ra dáng đàng hoàng. Lại có cả kho trữ thực phẩm.

Ngài ưng ý lắm, chuyển vào dinh thự mới, mời bọn Sẻ, Sâu đến chơi. Khỏi phải nói, chúng nó lác mắt thán phục, hết lời ca ngợi.

Từ hôm đó, cứ sáng sớm Bói-Cá lại ra cửa hát ông ổng, tinh thần phấn khởi.

Bặt đi mấy hôm không nghe tiếng hát, Sẻ và Sâu rủ nhau đến thăm. Đánh tiếng mãi không thấy ai, chúng ra bờ ao tìm, kinh ngạc bắt gặp Bói-Cá tiều tụy, thâm quầng, chân tay run rẩy.

Bói-Cá kể như mếu: - Thấy dinh cơ tốt, rộng rãi, lũ chuột tự tiện đến ở. Đuổi cũng không đi. Bọn này đã hôi lại xấu nết. Cá dự trữ nó ăn bằng hết. Suốt đêm sục sạo, làm mình không dám ngủ, chỉ lo lên cơn đói nó lại xơi tái miếng đùi... Hết chịu nổi, Bói-Cá tìm về tổ cũ thấy bọn cua cũng đã chiếm mất, lấp đất kín cửa hang, đành chịu cảnh màn trời chiếu đất mấy ngày nay... 


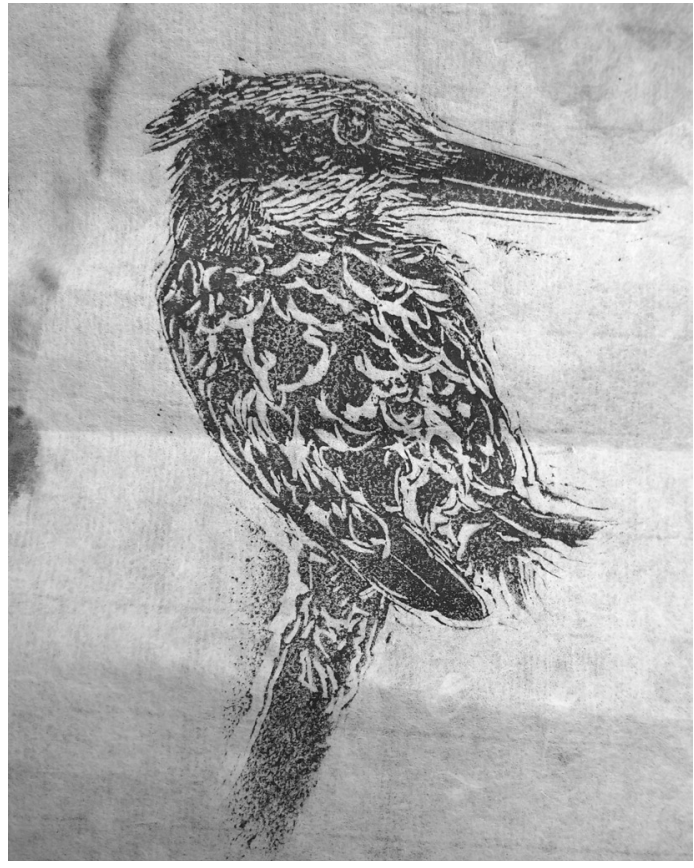

Bùi Quang Khiêm

\section{LIÊN DOANH!}

Mùa xuân nay, không hiểu sao cá ít hẳn. Bữa no bữa đói, khiến Bói-Cá ngẫm ngợi. Rồi kế nảy ra. Ngài có uy, nên gọi Cò đến bảo:

- Đánh bắt khó khăn, để no, ta phải liên doanh nuôi cá.

Cò gật gù, nói thêm:

- Xét ra, nuôi rô và diếc. Bọn này sống dai, đẻ nhiều.

Thống nhất phân công, cả hai chăm sóc chung, không phân biệt. Nhưng Bói-Cá chịu trách nhiệm và hưởng chính cá rô. Cò thì chuyên cá diếc. Ai chăm chính loại nào được hưởng 8 phần thu hoạch loại đó. Hết mùa tổng kết và chia nhau. Trong lúc nuôi trồng, không được tư túi của liên doanh.

Quả nhiên, rô và diếc lớn nhanh. Thức ăn thiếu thì bảo nhau đi kiếm thêm rau cỏ về. Đôi lúc cũng bồi dưỡng bọn cá cả giun dế giàu đạm. Chả mấy chốc, đã thấy đàn cá đông đúc bội phần.

Có bữa thèm lắm, Bói-Cá nhẩm tính, đông thế này bắt một con ăn cho sướng. Mà bắt diếc thì lợi vì nếu còn, cuối mùa thì 10 phần Cò hưởng 8 . Thói đời, ngon quen miệng, Bói-Cá ăn thường xuyên hơn. Rồi ăn hàng ngày. Mỗi lần ăn cũng tăng dần, từ một lên vài con diếc.

Thấy diếc vơi đi nhiều, Cò sinh nghi, hỏi Bói-Cá:

- Sao diếc bị mất đi đâu thế? Vài hôm mà thấy vơi hẳn?

Bói-Cá tảng lờ:

- Còn mất là chuyện của ông Trời, sao ta biết.

Dù không có bằng cớ là Bói-Cá ăn, nhưng vẫn nghi ngờ, lòng Cò buồn bực.

Vài tuần sau, Bói-Cá bỗng thấy cá rô trong ao vơi đi. Xưa nay, cá rô cũng là món khoái khẩu của Cò, nghĩ vậy Bói-Cá nghi cho Cò. Gặng hỏi vài lần, Cò chỉ nói:

- Rô cũng như diếc, chắc là cũng chuyện của ông Trời.

Bói-Cá lại càng nghi, liền nghĩ ra kế. Hôm tới hội xóm, nhân lúc Cò dự hội, sẽ lẻn về sớm, tạt qua nhà, điều tra đột xuất hiện trường xem có dấu vết của đám rô mất tích không.

Ngày hội đến, giữa lúc tất cả say sưa hát hò, Bói-Cá ba chân bốn cẳng chạy về nhà Cò. Chẳng khó khăn gì, đi vào phía sau, Bói-Cá sửng sốt lẩm bẩm:

- Chết thật, nguyên đống xương to. Toàn xương cá rô!

Chưa dứt lời, Bói-Cá nghe phía bên tổ mình giọng Cò la toáng:

- Chết thật, nguyên đống xương to. Toàn xương cá diếc! 


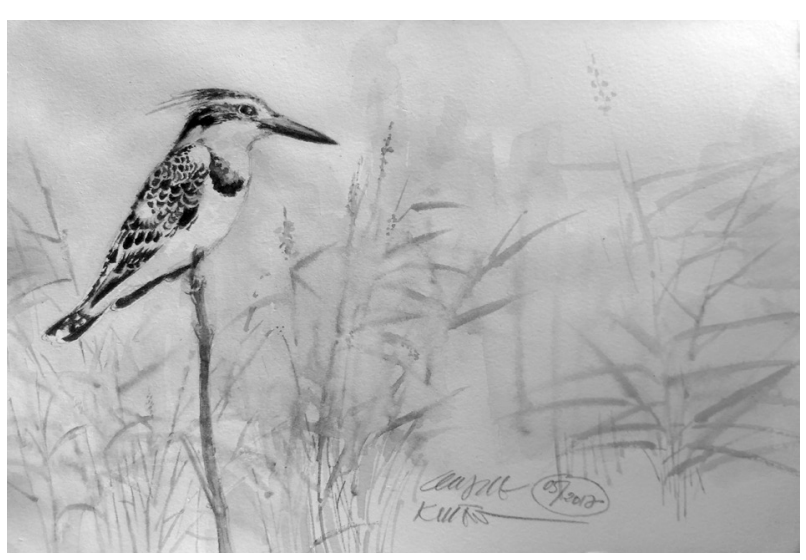

Bùi Quang Khiêm

\section{@bim) khồi}

Bói-Cá vốn tính điệu. Bộ áo cánh cầu kỳ, lúc nào cũng như đi hội. Quanh năm đánh bắt ở ao, việc soi gương, ngắm vuốt cũng thành thú vui. Càng ngắm, ngài càng thấy mình đẹp, chẳng có chỗ nào để chê.

Ngày nọ, hội đồng xóm chim quyết định tìm biểu tượng đẹp nhất, trao danh hiệu "chim khôi”. Có vài tiêu chuẩn. Tài kiếm sống là một. Tinh thần dũng mãnh, bay nhanh, mỏ cứng, vuốt sắc là hai. Bộ cánh đẹp, hình hài cân đối và khuôn mặt thanh tú là ba. Bói-Cá tự kiểm rồi kết luận:

- Dứt khoát "chim khôi” là Bói-Cá ta chứ chẳng thể khác được.

Theo lệ, sau khi hội đồng nhất trí, sẽ giao cho Cú - họa sỹ tài năng có trí óc tinh khôn - vẽ bức tranh chân dung. Ngày vinh danh sẽ treo tranh lên. Toàn thể các hộ chim trong xóm sẽ đồng thanh xướng tên. Bói-Cá mơ ngày ấy. Ngài đi vận động các bô lão hội đồng.

Vừa quà cáp, vừa ăn nói khéo léo, lại kể lể chỗ thân quen... Ngài lại hứa tài trợ cuộc thi bằng số cá tích trữ nhờ đánh bắt cả tháng, ăn uống kham khổ. Rốt cục ngài cũng thuyết phục được hội đồng trao danh hiệu "chim khôi" cho mình.

Vốn yêu cái đẹp, lại cũng để đảm bảo hình ảnh truyền thông, Bói-Cá quyết định hợp tác sâu sắc với Cú. Bức họa phải hoàn hảo mới được. Ngài mang đồ ăn, quà cáp đến, kè kè ở tổ Cú.

Bói-Cá cũng chẳng đòi hỏi gì nhiều nhặn, chủ yếu nhờ vả nét vẽ của Cú giúp cải thiện thẩm mỹ. Cốt sao có hình ảnh mạnh, can đảm và hoạt bát hơn. Thể hình tráng kiện hơn. Đôi mắt tinh nhanh hơn. Riêng mỏ cho bé lại chút, nhưng vẫn sắc bén, là ổn. Nói chung xứng đáng chim khôi.

Cú nể nang và cũng nhân dịp này trả ơn Bói-Cá giúp đỡ hồi thiếu đói, nên hợp tác nhiệt tình.

Bói-Cá đẹp lòng. Ngài ăn no, ngủ kỹ, ngóng phút đăng quang.

Ngày hội, chim nô nức kéo về.

Cỗ bàn bày ra. Thông báo thể lệ. Giới thiệu hội đồng... Sau đủ nghi thức, tới tiết mục chính: xướng danh "chim khôi”. Bói-Cá vờ khiêm tốn, nằm trong lùm cây, chổng mông về phía tranh. Đợi đám đông xướng tên.

Tranh được đưa đến. Mảnh khăn che gỡ ra. Đám chim dự khán ồ lên, đồng thanh hô:

- Diều hâu!

Châu Chàng 


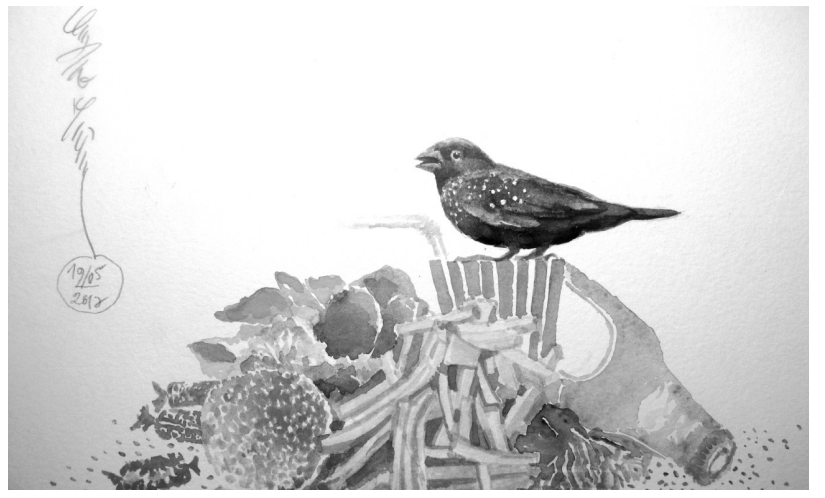

Bùi Quang Khiêm

\section{CÁI ĂN}

Dạo gần đây, họ nhà Sẻ đông lên, cái ăn lại khó kiếm hơn trước. Qua mùa gặt, nhà Sẻ bị đói ăn. Sẻ lớn nom hốc hác. Sẻ non xơ xác, suy dinh dưỡng. Nhìn Sẻ chỉ thấy đầu với mỏ. Sẻ bàn nhau đi học trí khôn của Bói-Cá và Chim-Lợn, tìm kế cứu sống nhà Sẻ.

Bói-Cá và Chim-Lợn thương lắm, đồng ý dạy cho trí khôn.

Bói-Cá chân phương:

- Thuận lẽ tự nhiên. Sinh nở đúng lúc, vừa phải thôi. Dạy bọn trẻ học bay nhảy. Rèn tinh mắt, sắc mỏ. Luyện khỏe cánh, chắc cơ. Chịu khó kiếm ăn ở đồng và vườn xa hơn. Tập ăn các loại hạt và sâu cho quen. Nhất định sẽ sung túc.

Sẻ vẫn băn khoăn. Lâu nay cố chịu vất vả mà nghe ngày no ấm còn xa xôi quá. Sẻ chờ kế Chim-Lợn.

Chim-Lợn nghĩ khác:

- Kế Bói-Cá chưa khôn. Kiếm ăn thì phải tới chỗ nhiều cái ăn. Bay xa rạc cánh, mà đâu chắc đủ ăn. Nhìn bọn chim Sâu xem, nhảy cả ngày vẫn đói, có lớn được đâu!?

Sẻ chột dạ:

- Vậy phải làm sao?

Chim-Lợn thong thả:

- Từ đây vào xóm làng người ở gần hơn. Ở đó, thóc lúa chật kho. Ăn không hết lại phơi cơm nguội. Trẻ con biếng ăn, thức ăn văng vãi quanh nhà. Ây là chưa kể hàng tuần họ mua đồ mới; thức ăn cũ bỏ đi. Thế thì còn lo gì cái ăn cho nhà Sẻ!?

Sẻ nghe xong, mắt sáng lên. Trông dáng vẻ Chim-Lợn to béo, sung túc, thấy lời nói càng đáng tin.

Từ đó, sớm sớm, rợp trời Sẻ bay vào làng. Hè nhà, bếp ăn, sân vườn... đều sẵn cái ăn. Lại phát hiện cả những đống rác to đầy đồ ăn. Sẻ bảo nhau:

- Ông Chim-Lợn quả là mưu trí. Từ khi vào xóm kiếm ăn đến giờ, chưa sai lời nào.

No ấm, đàn Sẻ lớn khỏe, lông cánh mịn màng. Sẻ già nghĩ xa:

- No rồi, phải dự trữ lâu dài. Nay chuyển hẳn vào xóm, ở các ống nứa, hốc mái, khe tường... để vận chuyển về kho nhanh, bớt công xây cất.

Đàn Sẻ rời xóm chim, định cư làng người. Có của ăn - của để, về thăm xóm chim thưa dần.

Một lần gặp Sẻ choai, Bói-Cá hỏi thăm, Sẻ bảo:

- Lo tích cốc phòng cơ, bận lắm nên ít về thăm.

Xong lại bay đi vội vã, ra dáng kẻ bận bịu.

Bẵng đi, chả còn thấy bọn Sẻ về nữa. Nhớ lũ Sẻ con, Bói-Cá nhờ Cò nhanh nhẹn đi thăm hỏi. Cò sốt sắng nhận lời, chiều về mệt lử nói:

- Vào tít trong làng, tìm mãi không gặp nhà Sẻ nữa. Hình như là chúng chuyển làng nào giàu hơn rồi!

Bói-Cá lẩm bẩm:

- Lạ nhỉ, sao mà khuân đống dự trữ được. Thế xóm làng thay đổi gì không?

Cò trả lời:

- Đông vui lắm. Còn có quán mới, đề biển “Chim Sẻ đủ món!”...

Chẫu Chàng 


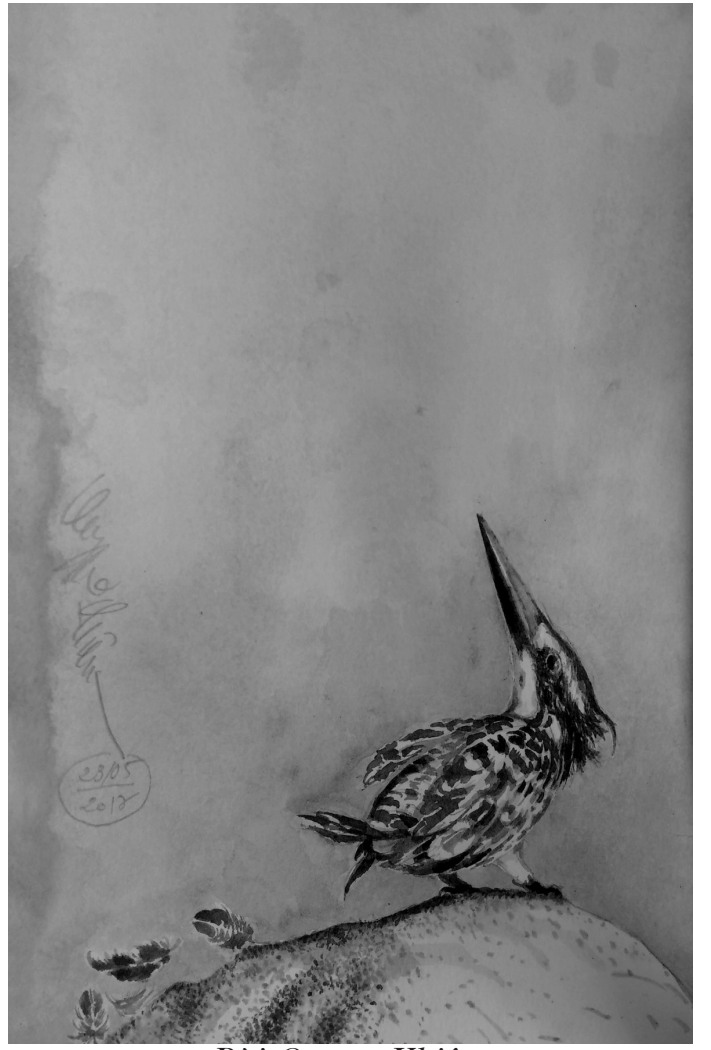

Bùi Quang Khiêm

\section{PHÉP TẮC}

Diều-Hâu là tay săn mồi ác chiến, chắc chỉ chịu thua Ủng hay Đại Bàng. Gã không hòa đồng, mà sống tách biệt. Dạo gần đây, do hay kiếm ăn trong làng, đôi lúc mới qua lại xóm chim, thoắt đến thoắt đi.

Sự xuất hiện của gã rất phiền toái vì gã chuyên bắt gà, vịt của làng người. Gã lại rất háu ăn, ngày nào không bổ xuống đàn gà ba, bốn bận, ngày đó chưa xong.

Bói-Cá lo lắng:

- Cứ đà này, rồi người ta sẽ lại săn chim, bù vào số gà bị mất. Tai họa thật khó lường.

Nghĩ đi nghĩ lại, chỉ còn cách cả xóm chim họp lại, gây sức ép với gã. Thế rồi, xóm yêu cầu Diều-Hâu tới buổi họp do Bói-Cá chủ trì, đủ loài lớn bé tới dự.

Chúng loài góp ý nhao nhao. Nào là, Diều-Hâu bắt mồi phải có phép tắc. Bắt gà cũng tùy nơi tùy lúc, không gây oán thù chất ngất. Nào là, săn bắt vừa đủ thôi, phải báo cáo xóm về số lượng. Một số còn động viên gã tập chén sâu bọ, thậm chí ăn chay...

Nghe xóm kêu gào, gã không nói gì, chỉ gườm gườm.

Bói-Cá hỏi Cò:

- Gã nghe có hiểu không nhỉ?

Cò đáp:

- Hiểu chứ, nhưng chưa biết ý ra sao. Vậy, từng phần một, bắt gã phải thống nhất với đại diện xóm, rồi mới họp tiếp.

Bói-Cá nghe lọt tai, liền đưa ra phiên tổng hợp ý kiến, có bốn phần phép tắc. Kết thúc mỗi phần, cắt cử một phiên dịch thống nhất lại, ghi biên bản với gã ở sau phòng họp. Điểm chỉ vào biên bản xong, mới bàn tiếp phần sau. Bốn đại diện là Sẻ, Gáy, Sáo và Khướu.

Từng phần một, dù phải thảo luận với đại diện hơi lâu, nhưng Diều-Hâu đều nộp lại biên bản đã nhất trí và điểm chỉ. Xong việc, Diều-Hâu về. Xóm tổng kết nốt rồi nghỉ, cảm thấy nhẹ nhõm.

Riêng Bói-Cá chưa yên tâm hoàn toàn:

- Xong biên bản, nhưng cần nghe ý kiến bốn đại diện!

Tìm mãi chẳng thấy bốn vị đại diện. Chỉ còn lại bãi lông cánh, lông cổ, vương vãi khắp gốc cây.

Chẫu Chàng 


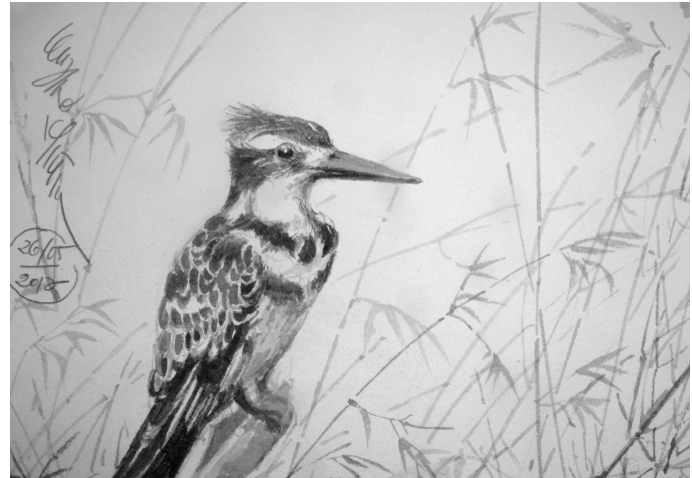

Bùi Quang Khiêm

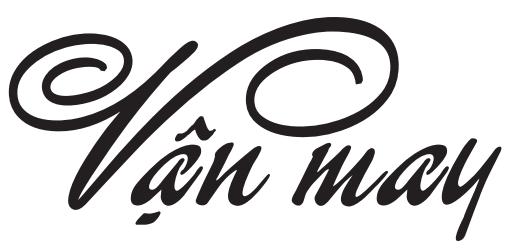

Vận may đến vào một ngày đẹp trời. Mới sáng sớm, Bói-Cá đậu trên cành còn chưa hết ngái ngủ, thì một con Diếc lờ đờ bơi đến... Không biết Diếc béo hay bụng đói mà bữa nay ngon miệng thế!

Đang ăn, thấy mắc trong cổ vật gì. Lôi ra, Ngài phát hiện một viên ngọc xanh, ánh hồng tuyệt mỹ, dường như trong bụng cá đã lâu.

Bói-Cá nghĩ: Báu vật may mắn. Cất thật kỹ!

Rồi lập tức mang về giấu kín trong hang sâu.

Lạ thay, vài ngày sau, Bói-Cá đã nghe chúng chim xì xào rằng Ngài trộm trứng nhà nào về cất trong hang. Kẻ độc mồm còn bảo, Ngài ăn phải cá biến đổi giới tính, nay bỗng đẻ trứng... Phải gan lắm, Ngài mới không phát điên. Rồi bọn chim cũng quên.

Chim quên, thì rắn nhớ. Nghĩ là trứng, bọn rắn nô nức mò vào hang. Dĩ nhiên là cắn rồi, gẫy răng mới biết nhầm. Chỉ khổ Bói-Cá mấy phen suýt bị bọn cạp nong mổ trúng. Chán thì chúng cũng bỏ đi. Còn Ngài rã rời sau nhiều đêm thức trắng.

Nhưng giữ cả ngọc quý lẫn bình yên sao mà khó thế... Có người trong xóm lúc tối qua bờ đê đầm nước, thấy ánh sáng hồng xanh phát ra từ hang. Đoán chừng chố ây có ngọc quý, hôm sau, hắn rủ nhiều người đi săn lùng.

Cảnh giác, Ngài đã đào nhiều chỗ giấu. Họ đục, thì Ngài chuyển. Chiến sự ác liệt, chỉ vài hôm mà xới tan bờ đê. Điệp khúc đào-dịch-đào-dịch... cứ thế vây hãm. Mỗi lúc, viên ngọc như một nặng thêm. Ngài lom khom mãi, đến sụn lưng, què cẳng. Lại còn nhịn đói mấy ngày.

Phải liều thoát!

Nhân lúc đám người đang ham đào xới, Ngài dùng mỏ cắp ngọc báu lao qua cửa chính. Liều hóa may: cửa hang bỏ ngỏ. Dù đói mờ mắt, Ngài hết sức bình sinh tăng tốc thoát ra. Đang mừng vì sắp qua cơn nguy, bỗng đâu có thằng bé tinh mắt nhìn thấy, nhanh tay phi cành cây gộc thẳng vào Bói-Cá.

Viên ngọc thì nặng, sức đã tàn, cú ném lại đầy uy lực... trước mắt Ngài như đã thấy Diêm Vương vẫy tay.

Hoảng loạn, kinh hãi, Ngài lập cập hoác cái mỏ ra. Thế là, viên ngọc rơi tõm xuống đầm nước.

Rớt mất viên ngọc, thân ngài lại nhẹ tênh. Ngài vọt lên, né cú va thần sầu. Gậy chỉ sượt qua, cũng dứt tung cả mảng lông Bói-Cá. Tý chết!

Đám người liền bỏ Bói-Cá, lao vào đầm lùng sục viên ngọc. Cả tháng sau vẫn còn đánh cãi nhau ầm ĩ.

*Hậu chuyện:

Mỗi khi nghĩ đến trận truy sát gớm ghiếc, đôi chân Ngài bất tuân ý chí, cứ run bần bật.

Tháng ngày qua đi, hôm nay, hiên ngang giữa xóm, Bói-Cá giảng bài:

- Sống ở đời, khi vào sinh ra tử, muốn còn toàn thây phải có trí khôn.

Đám chim học trò hỏi:

- Triết lý Ngài tâm đắc là gì?

Bói-Cá ưỡn ngược:

- Không tham của nả. Quăng báu vật cho lũ tham lam tranh cướp!

Hầu hết bọn chim non gật gù thán phục. Có vài đứa bụm miệng cười. Còn Ngài len lén nhìn chỗ bụng, nơi vận may ra đi và đám lông không bao giờ mọc lại. 


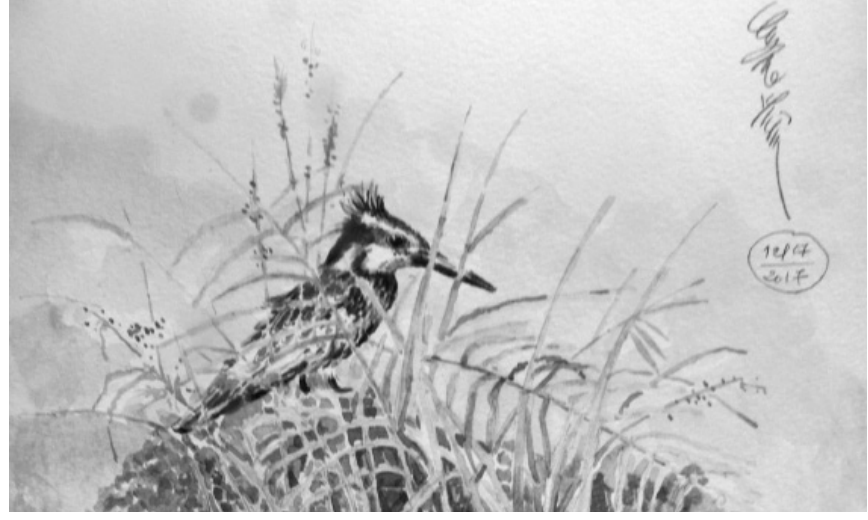

Bùi Quang Khiêm

\section{KỲ TÍCH}

Danh tiếng của Bói-Cá lẫy lừng. Cơ thể săn gọn, chỉ khoảng 40 gram. Nhưng, ăn khỏe! Mỗi ngày xơi 25 gram cá; mỗi tháng xơi cá bằng 20 lần trọng lượng cơ thể. Tốc độ sấm sét. Ngài vọt $40 \mathrm{~km} /$ giờ là thường. Họ nhà ngài bên Úc châu còn có kẻ chơi trội, bay trêu ngươi trước mũi xe hơi đang chạy $70 \mathrm{~km} /$ giờ! Sức bền cũng gớm. Có giống Bói-Cá di trú, mỗi đợt đi hơn $3000 \mathrm{~km}$, vừa bay vừa ngẫm sự đời.

Thiên hạ còn đặt nghệ danh "bói" cho tuyệt kỹ gia truyền: bay như kẻ chỉ, cắm mỏ lên mặt nước như đinh tán ri-vê, trong $1 / 4$ chớp mắt. Cá bắt rồi mà bọt nước vẫn chưa tóe lên.

$$
* * *
$$

Ngẫm mình đã no, tài khéo, tinh khôn có thừa, Ngài quyết giao lưu mở mang học hỏi thêm tuyệt kỹ.

Bọn Sơn-Ca, Họa-Mi, vui vẻ dạy ngài luyện thanh, học hát. Cao trong vắt, thấp trầm hùng... ngài hăng hái tiếp thu. Được cái hiểu đời, nhanh trí, chẳng mấy chốc say đắm âm nhạc.

Chơi với tụi Chào-Mào, Gà-Lôi, Chim-Công, ngài học cả thời trang. Tô mũ, tỉa áo...

Ngài còn học của Cú món ảo thuật quay đầu 360 độ.

Ngài càng rèn bí kíp các loài, thì tài lẻ gộp thành tài chẵn. Ngài thạo mọi thứ: đường nét cũng làm được, mà thuyết giảng chẳng thua ai.

Xóm chim nay được tín nhiệm tổ chức hội thi bắt cá cho anh tài khắp nơi. Bọn Bói-Cá nơi nào cũng vậy, vẫn bí kíp gia truyền ấy. Riêng Ngài lợi thế sân nhà và đầy mình tài nghệ. Chỉ có Ngài mới làm nên kỳ tích!

Đối thủ từ các nơi kéo về, ngày đêm luyện tập, chờ ngày thi thố. Riêng Ngài có thêm lịch: sáng hát, chiều thời trang, chập tối lại ảo thuật.

Sự việc này khiến đối thủ hoang mang, tủi thân. Nhưng, có than thở kém tài, thì bọn Bói-Cá cũng biết làm gì hơn ngoài bắt cá?!

Ngày thi, chục chiến binh dàn khắp mặt sông, hồi hộp chờ lệnh. Luyện rõ lắm, mà so tài chỉ một lượt bắt. Tính cả tốc độ, dáng vẻ, tinh nghề... Bô lão chưa ra. Nghe chừng căng thẳng, Ngài cất giọng hát, ra dáng kẻ học hành bài bản. Cả xóm vỗ tay. Tiếp đến, Ngài nhảy qua nhảy lại, còn điệu hơn sàn diễn, lông áo phất phơ. Khán giả lại được phen trầm trồ. Khi giám khảo ra, Ngài còn kịp xoay vòng ảo thuật, khiến xóm nức nở mãi chưa thôi!

Sau tiếng hô:

- Bắt cá!

Đồng loạt dàn Bói-Cá lao thẳng như kẻ chỉ. Trong nháy mắt, đáp nước êm ru. Cắp cá nhẹ nhàng, thuần thục vọt lên, như cảnh phim trong mơ.

Ngài lao như mọi ngày, nhưng không hiểu sao đường bay loằn ngoằn như bọn nhặng xanh. Lúc đáp, đập cái tõm, nước văng tóe. Rõ con cá ở gần, vươn mỏ bắt cặp, ba bốn lần vẫn trượt. Cuống quá, Ngài thò cả chân ra để túm. Ây, nhưng do bấn loạn, Ngài sặc nước ầm ĩ...

Cuối cùng cũng tóm được một con cá bột nhãi ranh. Lông ướt nhèm, bụng no nước, Ngài ê chề leo lên cành trong sự im lặng đáng sợ của cổ động viên.

Ngài đội sổ; giải anh tài thuộc về kẻ xứ khác.

Nhưng, bô lão trao cho ngài huy chương "Bói-Cá tạp kỹ".

Kỳ tích đồn xa: Gần trăm năm, mới lại có Bói-Cá sặc nước! 


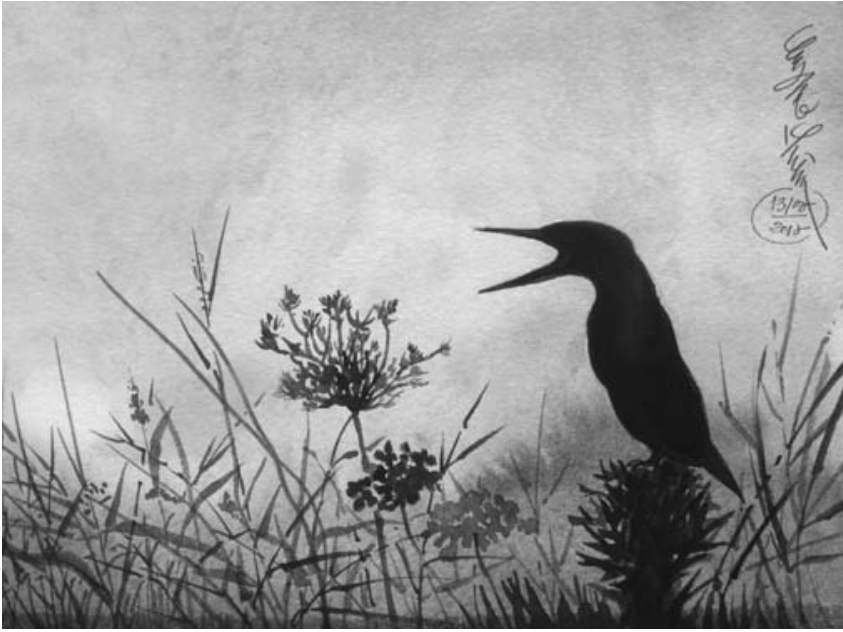

Bùi Quang Khiêm

\section{BÍ MẠTT KINH HOÀNG}

Lúc này, Bói-Cá làm tổ ở một góc yên tĩnh và kín đáo ven đê, để chiêm nghiệm việc đời.

Một ngày đầu hè, một gã chim lạ phương xa đến. Trông gã rất phong trần, rắn rỏi. Gã có vóc dáng dũng mãnh, ánh mắt uy lực, nhưng rất lịch sự. Gã có chỏm mào kỳ lạ màu tím trên đầu; sau này Bói-Cá đặt biệt danh "Mũ-Tím".

Mũ-Tím tới nơi vắng vẻ chỗ Bói-Cá làm tổ, lặng lẽ bay đến bên cạnh. Gã đậu xuống nhẹ nhàng khiến Bói-Cá giật mình suýt rơi xuống nước.

Mũ-Tím hỏi khẽ: - Ông là chủ chốn này phải không?

Bói-Cá: - Vâng, vâng... chính là tôi.

Ngài hơi lo lắng. Nghề "bói" gia truyền này dạy Ngài đậu ở nơi kín đáo, hơn nữa Ngài lại có tầm quan sát siêu đẳng. Vậy mà gã này tới đậu ngay cạnh, êm ru, Ngài không hề hay biết, đủ thấy nội công gã phải thâm hậu ghê gớm thế nào.

Mũ-Tím: Tôi muốn thuê hang của ông 3 ngày 3 đêm. Trong thời gian ấy, ông ở quanh bờ đê canh chừng cửa hang cả ngày lẫn đêm. Công xá tôi trả ông hậu hĩnh. Hơn nữa, khi ông gặp nạn, tôi sẽ trợ giúp.

Sau khi trao đổi, Bói-Cá đồng ý.

Mũ-Tím lại yêu cầu Bói-Cá sắm cho những đồ sau đây: 3 cật tre vót nhọn, dài 15 xăng-ti-mét; 1 gói diêm sinh 10 gam; và 1 sợi lông chim trĩ 5 màu.

Mũ-Tím không quên dặn lại là tuy canh chừng giúp, nhưng Bói-Cá tuyệt đối không được tọc mạch về việc sẽ nhìn và nghe thấy.

Ban ngày hoàn toàn yên tĩnh, nhưng đêm đến, những bí mật kinh hoàng xảy ra trong hang.

Đêm thứ nhất, Bói-Cá từ xa bờ đê nghe thấy những tiếng khóc lóc oán than văng vẳng ghê rợn, sau những tiếng rít như cung tên xé gió...

Đêm thứ hai, toàn những tiếng nỉ non não nề trong hang bập bùng ánh lửa vàng. Khói từ hang bay ra, chỉ phảng phất, mà cũng gây cho ngài xây xẩm mặt mũi, suýt ngất.

Đêm thứ ba, những tiếng hú hét man rợ khiến dựng tóc gáy. Trước khi tắt tiếng, một quầng sáng 5 màu ma quái rập rờn trong bóng đêm.

3 đêm ấy, ngài tuyệt nhiên không thể ngủ. Vừa sợ, vừa tò mò...

Hết 3 ngày, Mũ-Tím rời hang, trả công đầy đủ và lịch sự chào tạm biệt. Bói-Cá lao vào hang và sửng sốt thấy: mọi thứ y nguyên, đồ đạc ngay ngắn. 3 cật tre, 1 gói diêm sinh và 1 sợi lông chim trĩ đặt gọn gàng trong góc.

Từ hôm ấy, ngài cứ bị ám ảnh vì những sự ma quái diễn ra không thể lý giải. Ngài mất tự tin vào sự từng trải của bản thân.

Bẵng đi, lại một mùa hè. Mũ-Tím lại xuất hiện trước sự sửng sốt của Bói-Cá. Gã lại thuê hang 3 ngày và yêu cầu 3 cật tre vót nhọn, 1 gói diêm sinh, 1 sợi lông chim trĩ 5 màu.

Lại 3 đêm mất ngủ, nghe những âm thanh ghê rợn, ma quái, văng vẳng trong ánh lửa bập bùng kỳ dị...

Hết 3 ngày, Mũ-Tím lại trả công và từ biệt. Ngài vào hang, kiểm tra, để rồi lại sửng sốt thấy mọi thứ vẫn nguyên vẹn, ngăn nắp, như chưa hề từng có chuyện gì hồi đêm.

Đã biết trước, nhưng ngài vẫn đờ đẫn trí não, không tài nào suy đoán được điều kỳ quặc gì xảy ra. Sự ám ảnh kéo dài và ngài hồi hộp chờ ngày Mũ-Tím trở lại lần 3.

Ngài đã không nhầm. Lại ngày đầu hè, Mũ-Tím quay lại thuê hang, vẫn yêu cầu y hệt những lần trước: 3 cật tre vót nhọn, 1 gói diêm sinh, 1 sợi lông chim trĩ 5 màu.

Mọi chuyện vẫn diễn ra ma quái vào ban đêm, ngày càng bí hiểm và kinh hoàng hơn.

Hết 3 ngày, sau khi kiểm tra mọi thứ ổn thỏa, Bói-Cá quyết định hỏi Mũ-Tím về chuyện đã xảy ra trong những đêm ma quái.

Bói-Cá: - Tôi đã giữ lời hứa và phục vụ ông. Nhưng nếu có thể, ông cho tôi "mở mắt" về những âm thanh, ánh lửa và quầng sáng ma quái đã xảy ra. Nó vượt tầm hiểu biết hạn hẹp của tôi.

Chừng như có vẻ thông cảm, Mũ-Tím nói: - Nếu tôi nói những bí mật ấy, ông có dám hứa sống để dạ, chết mang theo không?

Bói-Cá: Tôi xin hứa. Ông cũng thấy, 3 năm qua, ở vùng này còn không ai biết ông đã từng tới đây...

Mũ-Tím gật đầu, nói tiếp: Vậy ông phải thề với trời đất.

Bói-Cá: Xin thề với trời đất sẽ không tiết lộ bất kỳ bí mật nào được nghe hôm nay.

Cuối cùng, Mũ-Tím đã kể cho Bói-Cá nghe về những bí mật kinh hoàng khiến ngài mất ngủ.

Bí mật ấy là gì?

Như đã thấy, Bói-Cá trọng danh dự, lại đã thề với đất trời. Đến giờ Ngài vẫn giữ bí mật ấy trong lòng. Vì thế, vẫn chẳng ai biết điều gì đã xảy ra những đêm hôm ấy cả.

Chẫu Chàng 


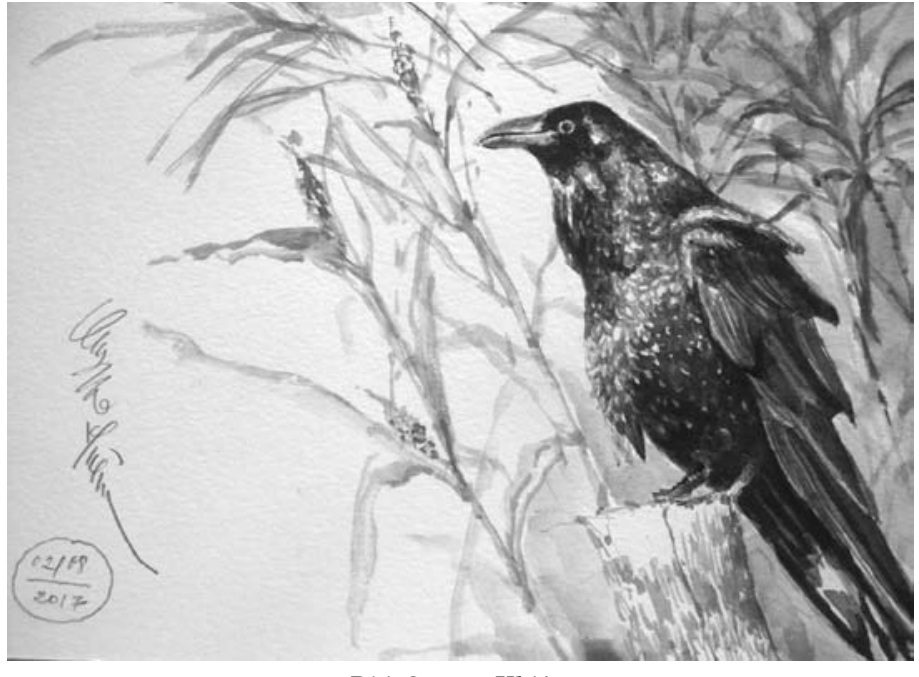

Bùi Quang Khiêm

\section{TOẠI NGUYỆN}

Đôi khi tài năng nở rất muộn. Ấy là trường hợp Bói-Cá. Chỉ dùng mỏ và các loại màu cây cỏ, đất đá, Ngài vụt thành họa sỹ lừng danh. Tài năng đắc dụng, Ngài được nhờ cậy đủ việc làm đẹp khắp xóm.

Ngày nọ, Quạ Đen tìm tới, trình bày chuyện hệ trọng:

- Cầu xin Ngài giúp rửa sự hổ thẹn của tổ tiên.

Bói-Cá: Nói ta nghe sự tình!

Quạ kể sự tích tổ tiên vẽ lông với Công. Quạ vẽ Công đẹp như tiên. Đến lượt Công vẽ, vì nóng ruột đi ăn cỗ, Quạ giục Công đổ mực đen vào cho mau xong. Từ đó, lông nhà Quạ đen thui thủi, xấu xí chả giống ai. Cái cục đau khổ muôn đời nuốt không trôi.

Thương tình, Bói-Cá nhận lời.

Giờ đây Quạ rất kiên nhẫn và tin tưởng giao phó. Bói-Cá trổ tài tạo nên tác phẩm màu sắc phong phú, tinh tế, hài hòa. Nhiều ngày mới xong. Cả hai lại cùng kiểm tra tỉ mi. Phải nói bộ lông tuyệt đẹp, quyến rũ có phần trội hơn Công.

Toại nguyện, Quạ-Đời-Mới cảm ơn và hăm hở về bầy.

Lại nói bầy quạ. Nay bỗng xuất hiện Quạ-Đời-Mới, nhận họ hàng, thì cho là quân lừa đảo. Chúng xúm lại đánh đuổi. Trải bao nhiêu trận tơi tả, kiên trì chịu đựng, mãi bầy mới hơi tin. Gã sốc...

Trở lại bầy, thì bị ghen ghét màu lông đẹp. Chúng tẩy chay. Có chỗ ăn, không rủ gã. Bị đói kinh niên, gã không dám ngủ. Trắng đêm dỏng tai nghe bầy xì xào để đoán đường kiếm sống. Gã mệt...

Nạn đói hết, trớ trêu thay bọn quạ quay sang thích màu lông đẹp. Chúng thay nhau xin lông để trang điểm, không thể từ chối! Nửa đêm đang ngủ lắm đứa còn lẻn đến nhổ trộm, đau buốt óc. Gã xơ xác...

Mãi sau, những rắc rối của bầy cũng bớt. Gã thích nghi...

Đúng khi cuộc đời sắp trả lại ngày tháng tươi đẹp, thì...

Dân xóm nhận ra bộ lông tuyệt mỹ, lấp lánh giữa bầy quạ đen thui. Họ đồn là chim thần. Nếu bắt được ngâm rượu thuốc, thì uống một chén sẽ trường sinh bất lão, cầu được ước thấy, khỏe đẹp như thần tiên!

Rồi đó, cả xóm họp thành đội săn hùng hậu, có đủ loại dụng cụ. Họ lùng sục ngày đêm truy bắt dường như không biết mệt. Mỗi ngày vài trận chết hụt, gã kiệt sức vì chạy trốn.

Cùng đường gã lết đến hang Bói-Cá, kêu khóc thảm thiết, kể lại những tháng ngày khổ sở cùng cực. Rồi, năn nỉ xin Ngài phục chế màu đen nguyên thủy.

Bói-Cá đành theo. Lần này, cách Ngài làm Quạ toại nguyện giống hệt cách Công làm thuở xưa.

\section{Chẫu Chàng}




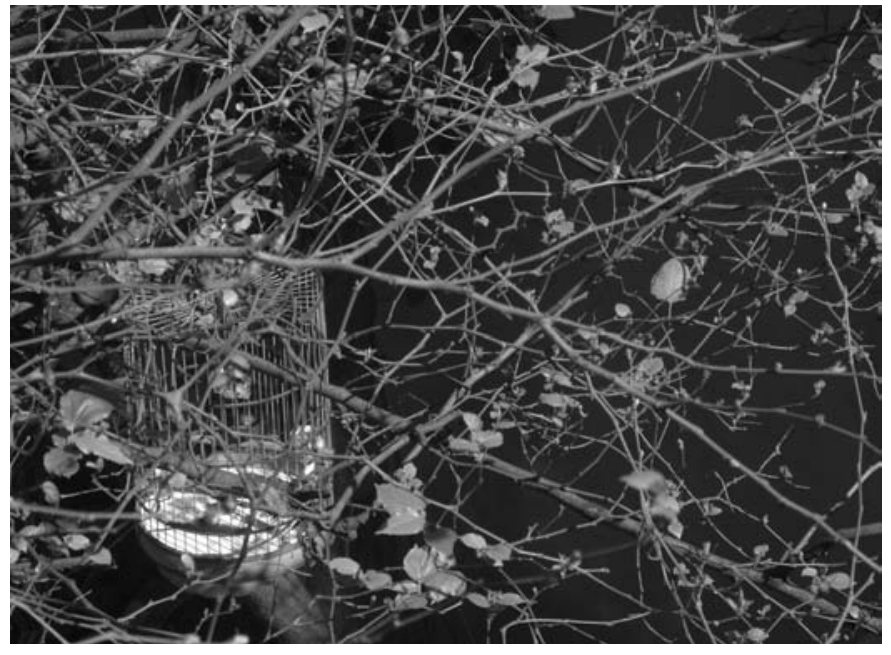

Bùi Quang Khiêm

\section{ƯớC MƠ}

Bây giờ, Bói-Cá kể chuyện cho bọn chim non trong xóm từ những điều mắt thấy tai nghe ở nơi phố thị.

$* * *$

Ấn nơi xóm vắng, đầu ngõ hiên ngang cây vối cổ thụ. Cuối ngõ, chỗ đôi căn nhà nhỏ xinh, lại nép mình một cây dâu ta.

Cây dâu có vòm lá xanh mướt bao trùm cả một khoảng sân rộng mênh mông. Những lúc ban trưa, vài tia nắng mỏng manh xuyên qua được những lớp lá dày, vẽ xuống sân những bông hoa nắng, khiến lữ khách ngẩn ngơ.

Hơn nữa, nó ra quả gần như quanh năm. Lớp lớp quả chín quả xanh mọc kề nhau liên tiếp.

Hót. Tiếng chim... Vòm lá diệu kỳ nơi xóm vắng ấy là mơ ước của bọn chim. Nhưng cũng là nơi giăng bẫy. Chủ nhà là tay mê chim hót hay; treo dưới bóng cây chiếc lồng tự chế 2 ngăn. Một bên là chú chim mồi hót véo von cả ngày. Bên kia cửa mở gọi mời, có sẵn nước uống... Bữa nọ, có chú Khướu rất đẹp theo tiếng hót, tìm đến cây dâu. Ăn quả no nê, chú khát nước, rồi chui vào lồng. Đang uống nước, cánh cửa lồng sập xuống. Chú chim tự do nay đã là tù binh.

Oan nghiệt!

Nó hoảng sợ, đâm đầu như điên vào vách lồng, hòng cố thoát. Vô ích. Cô chim bên cạnh vẫn véo von ca ngợi sự sống tươi đẹp... Rồi dâu chín lại được mang vào lồng. Nước uống tiếp thêm.

Thế rồi, Khướu ta không còn sợ nữa. Thì ăn, thì uống, nhưng không hót. Nó nào có biết hót. Hình thể đẹp mắt, chứ giọng hát, thì tuyệt đối vớ vẩn!

Thấy chim đẹp không hót, ông chủ chán. Một ngày, ông mở cửa lồng, trả lại tự do. Sung sướng, Khướu vọt ra khỏi cửa, bay lên, tận hưởng bầu trời trong xanh.

$$
* * *
$$

Cô chim mồi còn lại cô đơn. Rồi một sáng tinh mo, đang dụi mắt, nhận ra anh Khướu tự do hôm nọ đã quay lại ngăn lồng nơi từng bị giam cầm.

Kinh ngạc hơn, Khướu ta đã có kiểu nói của một triết gia. Gã tuyên bố:

- Ở đâu có thức ăn, nơi ấy có tự do! Ngăn lồng này là mơ ước của ta. Nơi đây, giây phút hạnh phúc nhất của ta đã đến. Chẳng cần phải hát mà vẫn có thức ăn ngon.

$$
* * *
$$

Bói-Cá nhận thấy ngăn lồng bên cô chim có tài ca hát luôn cửa khóa then cài, không một giây sơ sẩy. Từ lúc Khướu quay lại, tiếng hát của cô thêm phần ai oán. Nhờ thế, dụ được thêm rất nhiều chim. 


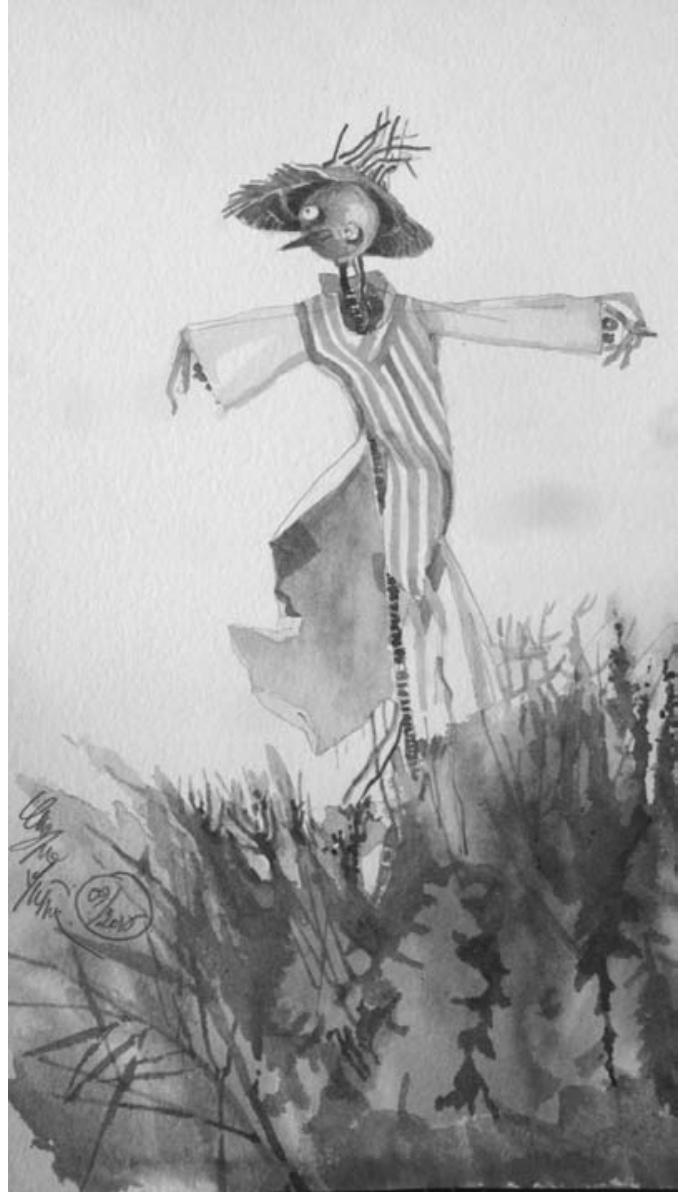

Bùi Quang Khiêm

\section{BÙ NHÌN}

Xóm người đông lên, ruộng vườn mở mang ra phía xóm chim. Ban đầu thì ổn, sau đó rắc rối bắt đầu kéo đến. Tụi chim tranh thủ thu hoạch hoa lợi từ chuối, na, tới rau và rồi cả lương thực như ngô. Người trong xóm bèn dựng các ông Bù Nhìn dữ tợn, tay chân nghều ngào, khiến lũ chim rất sợ, không dám bén mảng. Nhưng, rồi chúng cũng phát hiện ra Bù Nhìn chẳng qua là thứ rơm, tre quen thuộc, nên lại tiếp tục đánh chén.

Không khí thù địch lên cao. Chẳng bao lâu, vệ sĩ canh vườn mới xuất hiện, kết quả của thời đại công nghệ số: rô-bốt. Bọn "người" này tinh vi, vật liệu tốt, tư thế hiên ngang. Đặc biệt, mỗi rôbốt được trang bị nhiều phương tiện chiến đấu với bọn chim.

Thôi, thế là toi đời. Còn đâu rau màu, hoa quả... Bọn chim hết cách, đến hỏi cao kế của Bói-Cá. Nhiều kinh nghiệm, lại theo dõi kỹ thời sự công nghệ, Bói-Cá nói:

- Chúng bay gặp kẻ thù 4.0 rồi. Không nghiên cứu kỹ không được. Phải tìm hiểu kỹ hành vi, may ra mới có cách đối phó.

Một cơ số trinh sát viên được cử ra thăm dò, về báo tình hình.

Sẻ: Chúng bắn đủ thứ đạn súng, đứng cách 50 mét là chết hết cả rồi.

Xóm chim xanh mặt.

Sáo: Bọn rô-bốt khiếp lắm, thích cao là vọt cao, thích to là tự phình to.

Cả đám lè lưỡi.

Cò: Úi giời, ăn thua gì, bọn nó còn quát ra siêu âm. Dơi bay qua còn rụng xuống, nói gì chim.

Bọn chim chúi mặt, bịt tai.

Chim Sâu: Lại có mùi hăng hắc, như chất độc hóa học. Cách vài chục thước đã thấy gián, sâu, bướm nằm la liệt.

Khỏi phải tả nỗi kinh hoàng ám ảnh xóm chim. Nghe xong Bói-Cá bóp trán hồi lâu, thở dài:

- Ghê thế này, thì hết đường rồi. Cách cuối cùng là thuê bọn Chuột cố vấn. Bọn này vốn giỏi tránh bẫy, lại tinh nhanh.

Quả nhiên bọn Chuột tài. Chỉ đôi bữa sau, đã thấy gửi báo cáo tư vấn:

"Sau khi nghiên cứu thực địa, trèo cả lên cổ rô-bốt kiểm tra, chúng tôi kết luận nhur sau:

1. Các rô-bốt này rất hiện đại, có khả năng đuổi đánh chim.

2. Các thông tin báo cáo ngài yêu cầu xác nhận đều sai. Các trinh sát của ngài do sợ quá đều đưng nhìn rô-bốt tù khoảng cách ngoài 200 thước và tưởng tuợng.

3. Các rô-bốt tuy rất hiện đại, nhưng tù khi ra ruộng đuổi chim vẫn chưa hề được lắp pin". 


\section{Tài liệu dẫn nguồn (gốc)}

[1] Vương Quân Hoàng. (2017). Kế hoạch hoàn hảo. Kinh tế và Dự báo, 50(13), 66.

[2] Vương Quân Hoàng. (2017). Nhẹ gánh, thảnh thơi. Kinh tế và Dự báo, 50(14), 100.

[3] Vương Quân Hoàng. (2017). Gia truyền... Kinh tế và Dự báo, 50(16), 64.

[4] Vương Quân Hoàng. (2017). Chim sư. Kinh tế và Dự báo, 50(17), 100.

[5] Vương Quân Hoàng. (2017). Dinh cơ. Kinh tếvà Dự báo, 50(19), 64.

[6] Vương Quân Hoàng. (2017). Liên doanh. Kinh tế và Dự báo, 50(20), 64.

[7] Vương Quân Hoàng. (2017). Chim khôi. Kinh tế và Dự báo, 50(23), 64.

[8] Vương Quân Hoàng. (2017). Cái ăn. Kinh tế và Dự báo, 50(25), 64.

[9] Vương Quân Hoàng. (2017). Phép tắc. Kinh tế và Dự báo, 50(26), 64.

[10] Vương Quân Hoàng. (2017). Vận may. Kinh tế và Dự báo, 50(31), 64.

[11] Vương Quân Hoàng. (2017). Kỳ tích. Kinh tế và Dự báo, 50(32), 64.

[12] Vương Quân Hoàng. (2017). Bí mật kinh hoàng. Kinh tế và Dự báo, 50(34), 68.

[13] Vương Quân Hoàng. (2017). Toại nguyện. Kinh tế và Dự báo, 50(35), 64.

[14] Vương Quân Hoàng. (2018). Ước mo. Kinh tếvà Dự báo, 51(1), 72.

[15] Vương Quân Hoàng. (2018). Bù nhìn. Kinh tế và Dự báo, 51(2), 64. 